\title{
UM MUNDO INCLUSIVO É POSSÍVEL?
}

\section{Ronald Lobato}

Autor para correspondência: Ronald Lobato - ronaldlobato@hotmail.com

Economista pela UFRJ, Especialização em Estudos Avançados na Universidade de Barcelona em

Planejamento Territorial e Desenvolvimento Regional e ex-secretário do Planejamento do Estado da Bahia

A história da humanidade é um pouco a história do crescimento das forças produtivas, o que inclui desenvolvimento tecnológico e evolução dos sistemas culturais, sociais e organizativos.

O fato é que ao longo dos tempos, estudando a história se vê quanto caminhamos.

Mas para responder à pergunta do título deste artigo, convém encurtar a história e destacar a superação do feudalismo e mercantilismo, pelo modo de produção que se convencionou chamar de capitalismo.

Na verdade, para conquistar o direito de diversificar e multiplicar as unidades produtivas e incluir novos segmentos sociais, foi preciso realizar revoluções que abalaram sistemas monárquicos, como na Inglaterra, suprimiram outros, como na França, e implicaram na independência de países como os Estados Unidos da América do Norte.

Diferentes, mas com núcleos culturais bem claros e próximos. Revoluções que pregavam a liberdade, contestavam o poder do Estado, arbitrário no controle das atividades produtivas e de serviços, propugnavam pela economia de mercado, contestando resquícios feudais e monárquicos, ou adaptando-os de forma a modificar sua essência.
Como implicava no corte dos donos do poder, a questão democrática que pouco a pouco foi abrangendo segmentos anteriormente discriminados, com a compreensão de que todo ser humano era digno da cidadania.

Com o direito de participar na seleção de leis, normas e destino da sociedade, de opinar e pensar sem censura. Mesmo admitindo que muitas vezes, os que tinham poder tentavam e conseguiam bloquear - mercado livre e o direito das pessoas, pois somos humanos e quem tem poder social, político e econômico tende a querer usar estas vantagens relativas para influenciar nas normas, nas leis e os comportamentos de forma a torná-los "mais iguais" que os demais.

E essa tendência de abuso do poder, tão bem analisada pelos economistas neo-clássicos, que identificaram e analisaram o que conspirava contra a concorrência perfeita, sempre permitiu em maior ou menor grau a formação de cartéis, oligopólios e monopólios, bem como sociedades com regimes policiais, de exceção e totalmente ditatoriais.

E todas as crises que tivemos, a partir do século passado, foram originadas de características socialmente patológicas das degenerescências apontadas acima. A Primeira e a Segunda Guerra 
Mundial, a Crise de 29, As guerras de conquista reeditando o colonialismo que houve antes do capitalismo e sobreviveu durante toda sua existência, etc.

Até que a partir dos anos 80 do século passado, mas com fato emblemático ocorrido na década anterior, $\bigcirc$ abandono unilateral pelos EUA da conversibilidade de sua moeda em ouro, o que eram tendências oligopólicas foram se tornando mais dominantes e hegemônicas no concerto das nações e nos países isoladamente.

Este processo acelerou com a queda, sem guerras e sem conflitos maiores, da quase totalidade do socialismo real.

Junto com o fortalecimento de uma doutrina quase religiosa, que acredita que toda a riqueza é não só legítima, como proporciona eficiência e eficácia ao sistema econômico, gerou o predomínio de doutrina que entende que sem controle social e com governos reduzidos à sua expressão mínima, se pode confiar na mão invisível de Adam Smith ${ }^{1}$ que, não tão ingênuo, recomendava que se tomasse cuidado com as imperfeições do mercado.

O fato é que tem havido uma involução econômica, mas também social e política significativa, um pouco determinada pela desregulamentação do mercado e outro tanto determinada pelo triunfo de alguns postulados quase religiosos sobre a economia e a sociedade que estão sendo aceitas por grande parte da sociedade.

O economista francês Piketty ${ }^{2}$ têm demonstrado que a prevalência destas doutrinas fez com que, no século passado, principalmente a partir da sua segunda metade, voltássemos a ter níveis de desigualdade semelhantes aos péssimos indicadores que tínhamos no final do século XIX.

As crises do fim do século e, a pior delas, que se consolidou em 2008 e ainda não foi superada, foi gerada pela doutrina neoliberal que advoga a desregulamentação da atividade econômica e recomenda a concentração da renda e do poder como forma de garantir crescimento da sociedade. Entretanto, esta doutrina não tem sabido entregar seu paraíso. A Europa não conseguiu sair da crise e os países que estão menos sacrificados são os menos apologéticos das recomendações religiosas do Fundo Monetário Internacional (FMI), como o próprio recentemente reconheceu. Os Estados Unidos, que sofreu menos, não privatizou suas empresas públicas - federais, estaduais e municipais - que lá são efetivamente relevantes, apresentam taxas de desemprego e de informalização do trabalho crescente, aumento preocupante da miséria e concentração de renda.

Mesmo assim, apesar de a crise não ter sofrido nenhuma influência do pensamento e da ação da esquerda progressista remanescente no mundo, a concepção ideológica que exerce esta hegemonia sobre as sociedades é, com pequenas diferenças, mundial e, sem dúvida, motivadora das seguidas crises econômicas e políticas pelas quais o mundo vem passando.

Significa dizer que apesar do fracasso pragmático da doutrina dita neo-liberal, porque nada tem de libertária, mas sim de controle da maioria pela minoria poderosa, a deterioração das sociedades se espalha ao longo do mundo, principalmente entre os países mais fracos, os com menos autonomia e os de cultura, latu sensu, menos diversificadas.

Significa também o desgaste ou abandono de máximas ou diretrizes filosóficas básicas do pensamento liberal, tais como a defesa dos fracos, a igualdade de oportunidades, a imprensa livre.

Substituídas pela alteração/consolidação de regimes quase policiais e de exceção, reprimindo segmentos importantes da sociedade, ou quem a eles se opõem, até nos EUA onde a revolução da independência cunhou $\circ$ conceito de que cada cidadão deveria se armar para impedir que 0 governo usasse sua força para dominar sociedade de forma não democrática.

Princípios e direitos foram esquecidos e principalmente um direito e objetivo fundamental: - de busca da felicidade. Substituído por um argentarismo e consumismo capazes de nos levar a barbárie e à infelicidade social e também pessoal. No Brasil, ao invés de valorizarmos a nossa escala, a nossa população, a nossa diversidade, a nossa riqueza nacional natural, também aderimos a uma defesa hipócrita do equilíbrio orçamentário e aos princípios da doutrina neo-liberal. 
Hipócrita porque propõe diminuir ainda mais os serviços públicos em saúde, educação, segurança, em nome de uma austeridade irrealista. Projeto que não considera a necessidade de uma reforma tributária inclusiva, capaz de reduzir a carga tributária, diminuindo os impostos sobre o consumo, mas reproduzindo os parâmetros dos outros países capitalistas no que diz respeito aos impostos sobre a renda e o patrimônio.

Sem este programa complexo a equação do equilíbrio é insustentável, pois os cortes nas despesas e nos investimentos públicos, geram redução das atividades e da arrecadação de tributos, formando um círculo vicioso de deterioração como assistimos desde 2015. Agravado agora em 2016, a partir de maio, quando recrudesceu a inspiração neo-liberal, acompanhada da orientação de desinvestimento público, redução das despesas públicas, ao mesmo tempo que erraticamente algumas são aumentadas. E tudo isso sem tentar resolver o problema da dívida interna e os juros praticados no país, usando como argumento que a única forma de combater a componente demanda da nossa inflação através dos elevadíssimos juros da taxa SELIC e dos bancos, que ficaram sem controle a partir da liberação da lei de usura decidida nos anos 90. Disputa-se, com razão, os aumentos nos impostos sobre o consumo, da ordem de 0,5 a $2 \%$ e não se comenta a componente inflacionária e tragédia social resultantes de juros da ordem de $300 \%$ ao ano.

O resultado é, entre outros, a migração total ou parcial de muitos empresários da condição de empreendedor para a de rentista, o que, definitivamente, acelera a disfuncionalidade de um capitalismo que não percebe que a macrocefalia do setor financeiro cancela sua fundamental importância no funcionamento do sistema de mercado, para sua desfiguração e perda de eficiência.

Piketty ${ }^{2}$, otimista ou ingênuo, clama pela clarividência dos líderes empresariais e da sociedade em perceber para onde estamos sendo levados pelas tendências dominantes a partir da segunda metade do século passado.

Mas não deixa dúvida para onde as curvas destas estradas da realidade estão nos levando. de consumo, promover a cidadania e os direitos de toda a sociedade, principalmente de suas minorias, cobrar impostos na proporção da renda e patrimônio do que cada um dispõe é a forma capaz de garantir mercado, acelerar o desenvolvimento tecnológico, a eficiência e eficácia da economia e da sociedade demonstra uma miopia abissal que nos levará de volta à barbárie, que no século passado pensávamos que tivesse sido superada para sempre.

\section{REFERÊNCIAS}

1. Smith A. A riqueza das nações: investigação sobre sua natureza e suas causas. $3^{\circ}$ edição. Rio de Janeiro: WMF Martins Fontes; 2016. P.371-399

2. Piketty T. O Capital no século XXI. Rio de Janeiro: Editora Intrínseca Ltda; 2013. P. 457-498

Não perceber que, incorporar massas ao mercado 